\title{
Academic Motivation Scale: Development, Application and Validation for Portuguese Accounting and Marketing Undergraduate Students
}

\author{
Rui Silva ${ }^{1}$, Ricardo Rodrigues ${ }^{2} \&$ Carmem Leal $^{3}$ \\ ${ }^{1}$ Polytechnic Institute of Porto, Felgueiras, Portugal \\ ${ }^{2}$ University of Beira Interior, Covilhã, Portugal \\ ${ }^{3}$ University of Trás-os-Montes Alto Douro, Vila Real, Portugal \\ Correspondence: Rui Silva, School of Technology and Management, Institute Polytechnic of Porto, Felgueiras, \\ Portugal. E-mail: rrs@estg.ipp.pt
}

Received: September 7, 2018

doi:10.5539/ijbm.v13n11p1
Accepted: September 30, 2018

Online Published: October 12, 2018

URL: https://doi.org/10.5539/ijbm.v13n11p1

\begin{abstract}
The purpose of this research is the adaptation of the Academic Motivation Scale (AMS) and its use on Accounting and Marketing college undergraduates. After the AMS had been adapted and changed into the Accounting and Marketing Academic Motivation Scale (AMAMS), it was validated in psychometric terms so that it could become a valid tool to be applied and used in studies involving this type of students. Using structural equation modelling, the AMAMS that resulted from adapting the original AMS model was tested. The new scale thus obtained has produced significant results that were very similar to those of the original scale, which means that it is valid and can be applied to other contexts. The validity and statistical reliability of the new scale made it possible to measure Accounting and Marketing college undergraduates' motivation in a reliable and robust way. The present research is an important contribution for literature since it is the first time that AMS is adapted to and validated in students of these two areas of management, although it has already been applied to several educational contexts.
\end{abstract}

Keywords: academic motivation scale, amotivation, intrinsic motivation, extrinsic motivation

\section{Introduction}

Higher Education plays an extremely important role in a country's growth and development. Therefore, it is essential that the powers that be are fully aware of its present situation.

Measuring the impact and quality of education can be a very difficult task, for it depends on several factors and contexts, such as access, number of enrolments, number of students who graduate, drop-out rate, among others. Therefore, it is relevant to understand how the main actors (the students) interacting in this process feel.

Lack of motivation has been deemed a predictor of students' academic achievement and is correlated with expected results like students' academic performance and their attitudes in an educational context (Barkoukis, Tsorbatzoudis, Grouios, \& Sideridis, 2008; Gottfried, Marcoulides, Gottfried, Oliver, \& Guerin, 2007). Therefore, new instruments must be created that can effectively and robustly measure student motivation in a given context, place and field of knowledge (Palacios \& Arias, 2014).

Motivation can become an important indicator of all the factors that should be taken into account in the teaching-learning process so that changes can be made to improve what needs improving and maintain what is being properly done. Consequently, knowing all the motivational processes that have to do with students and assessing them can provide one with information on what paths to follow and what policies to implement to improve academic achievement.

Despite its complexity, motivation in general, and, in particular, its measuring have become more and more relevant in academia, and led to the creation of strategies to understand and enhance its applicability (Glynn, 2007). It has been looked into from different theoretical perspectives, among which the Social Cognitive Theory (Pintrich, Smith, Garcia, \& McKeachie, 1993), a Expectancy Value Theory (Wigfield, 1994) and the Self Determination theory (Ryan \& Deci, 2000c) stand out as the main references on the subject.

Motivation can show itself in many ways in student behaviour, involving not only students themselves, but also 
the education system as a whole, their families, and the social environment enveloping them, among other personal, intrapersonal, interpersonal, contextual and situational elements (Vallerand \& Blssonnette, 1992). It is linked to student learning (Chiu \& Chow, 2010; González \& Paoloni, 2015; Yen, Tuan, \& Liao, 2011), and has been scientifically evaluated by several authors due to its influence on the learning process (Deci \& Ryan, 2000).

Several studies have pointed to motivation as being directly responsible for the retention of knowledge (Alivernini \& Lucidi, 2011; Huett, Kalinowski, Moller, \& Huett, 2008; Tinto, 2006), although results may vary according to the students' learning level and skills, cultural aspects and learning contexts (Taylor et al., 2014). Using different measurement tools, several studies have shown that students with higher motivational levels usually attain better results (Goldschmidt \& Bogner, 2016; Tseng \& Tsai, 2010).

Attendance is also a recurring research theme and is considered an important predictor of academic performance (Alzhanova-Ericsson, Bergman, \& Dinnétz, 2017; Credé, Roch, \& Kieszczynka, 2010; Morrissey, Hutchison, \& Winsler, 2014).

Motivation is a constantly changing process that can have either positive or negative results (Brouse, Basch, LeBlanc, McKnight, \& Lei, 2010; He, Gajski, Farkas, \& Warschauer, 2015; Nilsson \& Stomberg, 2008). In order to scientifically study this complex construct, researchers have often resorted to the Self Determination Theory (SDT), which is considered one of the broadest and most complete theories on motivation, and one that explains how and why motivation affects human behaviour and what results from that (Deci \& Ryan, 1985).

Several authors have applied the SDT theoretical framework in various studies regarding university motivation in order to find out what drives students to decide to study or continue to study (Vallerand et al., 1993). To that effect, they have used several tools and/or scales resulting from the SDT theoretical framework, especially the Academic Motivation Scale (AMS).

Originally developed in France (Vallerand, Blais, Brière, \& Pelletier, 1989), the AMS was later translated into English (Vallerand et al., 1992), the language it was used in a great number of studies.

Meanwhile, researchers all over the world have been using the SDT to measure intrinsic and extrinsic student motivation in different samples and educational contexts (Deci \& Ryan, 1985; Ryan \& Deci, 2000b). In their studies, the AMS has proven to be very effective in measuring student motivation. Despite extensive testing, especially in the last decade, there is still no study that validates AMS in the case of Accounting and Marketing undergraduates. The need to validate the scale and apply it to different contexts and samples grants the present study academic relevancy.

Therefore, the main purpose of this research is to validate AMS regarding Portuguese students, who attend Accounting and Marketing in Universities and Polytechnic Institutes in Portugal.

\section{Literature Review}

\subsection{Self Determination Theory}

Education professionals recognise motivation's essential role on academic achievement (Pintrich, 2003). One of the theories more commonly used to study and explain the importance of student motivation is the Self Determination Theory (SDT) by Ryan \& Deci (2000). According to these authors, students develop their skills better when they derive pleasure and are satisfied with their choices. This theory distinguishes between intrinsic and extrinsic motivation, that is, between autonomous and controlled motivation, the former being considered high quality motivation, and the latter low quality motivation (Deci \& Ryan, 2008; Ryan \& Deci, 2000a).

The different types of motivation addressed in the SDT are perceived as different ways of individuals regulating their driving force: of being internally or externally motivated to perform certain tasks and display a certain behaviour (Deci \& Ryan, 2008; Ryan \& Deci, 2000a). According to the SDT, motivation is a multidimensional concept that can be divided into several types (Amotivation, Intrinsic Motivation and Extrinsic Motivation), which, in turn, reflect individuals' different levels of self-determination (Deci \& Ryan, 1985).

Amotivation (AMOT) is characterised by the individual's lack of willingness or motivation (intrinsic or extrinsic) to engage in an activity and his/her feeling incompetent or failing to carry out a given procedure.

The Extrinsic Motivation (EMOT) results from one's commitment to perform a task as a means to reach a certain goal and it can be divided into several types or levels, ranging from the lowest to the highest level of self-determination. In the self-determination continuum, EMOT presents itself in four stages, in ascending order: external regulation (EMER), introjected regulation (EMIN), identified regulation (EMID) and integrated regulation (EMIR) (Deci, Koestner, \& Ryan, 2001; Deci \& Ryan, 1985).

The external regulation is the one that best describes external motivation. In other words, the individual performs 
a certain task because there is an extrinsic motivation that drives him/her to avoid punishment or receive a reward. He or she responds to external stimuli that do not take into account his/her own interests, wishes or goals. This is the least autonomous form of motivation, guided by external contingencies, such as the incentives given by teachers and/or colleagues in the course of the learning process (Ryan \& Deci, 2000a).

The introjected regulation already involves some degree of internalising motives, but individuals still act more out of an obligation or pressure, rather than on their own free will. Students, for example, may display a certain behaviour because they feel pressured by others and not because they choose or wish to do so (Deci et al., 2001).

When a person is motivated by identified regulation, they identify themselves with the value of the task they are about to perform, acknowledging its importance and making decisions in a somewhat autonomous manner. One can say there is identified regulation when students identify with a certain school assignment and accept it voluntarily by regulating their behaviour accordingly (Deci et al., 2001).

Finally, the integrated regulation values a person's choices, decisions and actions, although they are not entirely independent of some external influence. In this context, student behaviour, when performing a certain assignment, is viewed as being personally important to attain the goals that have been set by students themselves in an almost autonomous way (Deci et al., 2001).

On the other hand, the Intrinsic Motivation (IMOT) is the type of motivation that involves the highest degree of self-determination; it occurs when individuals are interested in a particular activity out of their own free will for the pleasure and satisfaction they derive from it (Ryan \& Deci, 2000a).

According to the Tripartite Model of Intrinsic Motivation developed by Carbonneau, Vallerand, \& Lafrenière (2012), the IMOT is divided into three unordered subscales: Intrinsic Motivation To Know (IMTK), which assesses the wish to engage in an activity for the pleasure and satisfaction one derives from the learning experience; Intrinsic Motivation To Accomplish (IMTA), which assesses the wish to engage in an activity for the pleasure and satisfaction of doing or creating something; and Intrinsic Motivation To Stimulate - (IMTS), which measures the wish to engage in an activity that is challenging and stimulating (Deci \& Ryan, 2008).

SDT applied to education focus on understanding whether student motivation is either autonomous or controlled, trying to predict results that have to do with students' outcomes in a learning context, thus getting a better picture of the meaning and relevance the learning process has for them and of how much motivated they are (Vansteenkiste, Lens, \& Deci, 2006).

The several types of motivation stemming from SDT have been used in various studies and in different levels of education with positive results, in which experience, the relevance of the learning and the intent to complete the course have stood out (Alivernini \& Lucidi, 2011; Hardre \& Reeve, 2003; Jang, 2008; Otis, Grouzet, \& Pelletier, 2005; Utvær, 2014; Vallerand, 1997; Vallerand et al., 1992; Vansteenkiste et al., 2006).

Other studies, on the contrary, have pointed to negative results, especially as regards important aspects, such as the intention to give up the course (Hardre \& Reeve, 2003) and effective student dropout (Vallerand, 1997).

In view of its robustness, that has been established in the literature over time, one of SDT's most frequently used tools is the Academic Motivation Scale (AMS) developed by Vallerand, Blais, Brière, \& Pelletier (1989).

\subsection{Academic Motivation Scale}

\subsubsection{Development, Interpretation and Validation}

The AMS is based on the SDT, which is a theory that explains how individuals regulate their intrinsically and extrinsically motivated behaviour according to their values, goals and intentions in a certain environment or context (Deci \& Ryan, 2012).

The original version of the scale was developed in France by Vallerand et al. (1989) and was called Échelle de Motivation Éducation (EME); it was based on the assumption that motivation processes were of a multifactorial nature. The scale was first tested on college students in Canada and it confirmed the existence of seven dimensions that were in line with SDT tenets. It was later translated into English, leading to the AMS (Vallerand et al., 1992). The AMS was also tested on Canadian college students, corroborating the seven-factor structure of the French version.

Figure 1 shows SDT's different types of motivation or regulation that range from the highest to the lowest level of self-determination, autonomy and feeling of control; in other words, from amotivation to total motivation (Ryan \& Deci, 2000c). 


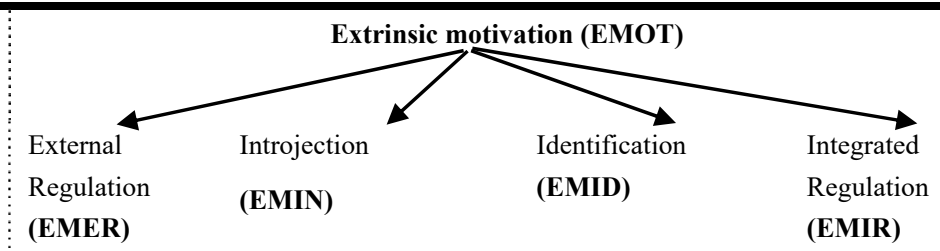

Figure 1. Self-determination continuum

Source: Adapted from Ryan and Deci (2000b).

The AMS uses only seven of the eight subscales of Ryan's \& Deci's (2000b) Self-determination continuum, measuring three types of motivation in a self-determination growing scale that begins with Amotivation (AMOT), moves on to Extrinsic Motivation (EMOT) and ends with Intrinsic Motivation (IMOT) (Vallerand et al., 1992, 1989). It should be noted that, within EMOT, AMS does not measure EMIR, which is also referred to in SDT, because it involves only older students, who, according to the authors, have developed a higher awareness of their own identity; therefore, when measured together with younger students, that can lead to biased results (Wang, Hagger, \& Liu, 2009).

Lying on the multifactorial nature of motivation processes, AMS is composed of 28 items subdivided into a seven-point Likert-type scale, ranging from "Does not totally correspond" to "Totally corresponds". These 28 items are divided into three main scales - AMOT, EMOT and IMOT; the AMOT has 4 variables and EMOT and IMOT 12 variables each.

Vallerand et al., (1992) suggested that answers to AMS should follow a certain pattern, in which strong positive relationships between different adjacent subscales should be expected when compared to more distal subscales in the SDT continuum. In other words, the Extrinsic Motivation subscales must have a stronger positive correlation among themselves than with Intrinsic Motivation subscales.

The AMS, validated by means of Confirmatory Factor Analysis (CFA), has been translated, adapted and applied in several countries, which shows the reliability and validity of the scale's psychometric properties. As shown in Table 1, it has been used both in Secondary Schools and in Universities.

Table 1. Main studies on the application of AMS in different countries (1989-2017)

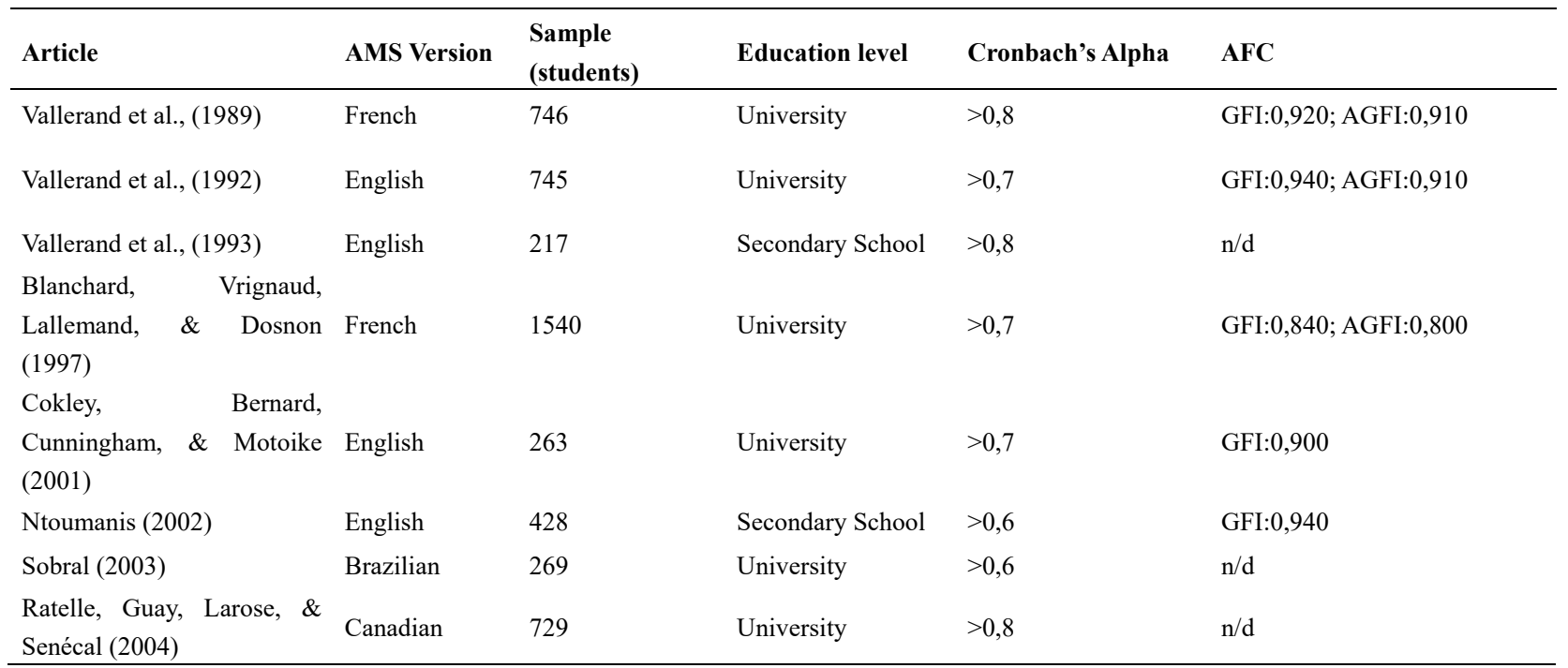




\begin{tabular}{|c|c|c|c|c|c|}
\hline $\begin{array}{l}\text { Fairchild, Horst, Finney, \& } \\
\text { Barron (2005) }\end{array}$ & English & 1406 & Secondary School & $>0,7$ & GFI:0,967 \\
\hline Núñez Alonso, Martin-Albo & & & & & \\
\hline $\begin{array}{l}\text { Lucas, \& Navarro Izquierdo } \\
\text { (2005) }\end{array}$ & Spanish & 636 & University & $>0,6$ & GFI:0,870 \\
\hline $\begin{array}{l}\text { Ratelle, Guay, Vallerand, } \\
\text { Larose, \& Senécal (2007) }\end{array}$ & Canadian & 942 & University & $>0,7$ & $\mathrm{n} / \mathrm{d}$ \\
\hline Alivernini \& Lucidi (2011) & Italian & 426 & Secondary School & $>0,8$ & GFI:0,916 \\
\hline $\begin{array}{l}\text { Barkoukis, Tsorbatzoudis, } \\
\text { Grouios, \& Sideridis (2008) }\end{array}$ & Greek & 911 & University & $>0,7$ & GFI:0,890; AGFI:0,870 \\
\hline $\begin{array}{l}\text { Spittle, Jackson, \& Casey } \\
\text { (2009) }\end{array}$ & Australian & 324 & University & $>0,6$ & $\mathrm{n} / \mathrm{d}$ \\
\hline $\begin{array}{l}\text { Smith, Davy, \& Rosenberg } \\
\text { (2010) }\end{array}$ & English & 2028 & University & $>0,7$ & GFI:0,940 \\
\hline Joly \& Prates (2011) & Brazilian & 170 & University & $>0,8$ & $\mathrm{n} / \mathrm{d}$ \\
\hline $\begin{array}{l}\text { Maurer, Allen, Gatch, } \\
\text { Shankar, \& Sturges (2012) }\end{array}$ & English & 475 & University & $>0,7$ & $\mathrm{n} / \mathrm{d}$ \\
\hline $\begin{array}{l}\text { Stover, de la Iglesia, } \\
\text { Boubeta, \& Liporace (2012) }\end{array}$ & Argentinean & 723 & University & $>0,7$ & GFI:0,962; AGFI:0,953 \\
\hline $\begin{array}{l}\text { Vecchione, Alessandri, \& } \\
\text { Marsicano (2014) }\end{array}$ & Italian & 419 & University & $>0,7$ & GFI:0,998 \\
\hline Can (2015) & Turkish & 797 & University & $>0,8$ & $\mathrm{n} / \mathrm{d}$ \\
\hline $\begin{array}{l}\text { Guay, Morin, Litalien, } \\
\text { Valois, \& Vallerand (2015) }\end{array}$ & Canadian & 4498 & University & $>0,8$ & GFI:0,900; AGFI:0,940 \\
\hline Buckley \& Doyle (2016) & Irish & 156 & University & $>0,7$ & $\mathrm{n} / \mathrm{d}$ \\
\hline Tóth-Király et al., (2017) & Hungarian & 1163 & University & $>0,8$ & GFI:0,910 \\
\hline
\end{tabular}

Several studies have shown that the correlations between IMOT and the most proximal EMOT subscales (EMID) are positively stronger than the more distal ones (EMER) (Alivernini \& Lucidi, 2011; Otis et al., 2005). Other studies, however, indicate that such correlations do not always occur, contrary to what is suggested by the SDT (Cokley et al., 2001; Fairchild et al., 2005). More recent studies have provided a general overview of the literature as regards AMS scales' reliability and correlation pattern (Can, 2015; Guay et al., 2015).

Ever since AMS was first developed in 1989, it has been used with all types of audience, including college students (Guay et al., 2015; Núñez Alonso et al., 2005) and in university courses, namely Business (Smith et al., 2010), Psychology (Cokley et al., 2001; Ramos, 2013), Physical Education (Spittle et al., 2009), Dentistry (Orsini, Evans, Binnie, Ledezma, \& Fuentes, 2016), Physics, Mathematics and Nutrition (Lim \& Chapman, 2015; Maurer et al., 2012; Sturges, Maurer, Allen, Gatch, \& Shankar, 2016), among others, which gives us a clear indication this is a scale that can be adapted to any field of knowledge. In the case of the present research, it can be translated into Portuguese and specifically adapted to the Curricular Units (CUs) under survey.

The scale also allows us to study gender-based differences, establishing men's and women's levels of self-determination. As a matter-of-fact, literature shows that, in general, women are more self-determined than men ( Acisli, Metin, \& Kolomuc, 2012; Eymur \& Geban, 2011; Núñez Alonso et al., 2005; Smith et al., 2010; Spittle et al., 2009; Vallerand et al., 1992).

The present quantitative study proposes to test and validate AMS constructs by means of factor analysis, looking into the internal consistency of items and factors in University students attending Accounting and Marketing for the first time. Validation of this scale applied to these two areas of Management will help build a new resource that can be used to measure student motivation regarding this field of knowledge, assessing its current state and giving indications as to what measures should be taken to improve it.

\subsection{Goal and Research Questions}

Using data gathered from students who attended Accounting and Marketing in various Portuguese Higher Education Institutions in the 2017/2018 academic year, the present study aims at adapting and validating Vallerand's et al., (1992) original AMS, by building an Accounting and Marketing Academic Motivation Scale (AMAMS) and testing its psychometric quality as regards its reliability and statistic validity. 
In order to fully attain the purposes of this research, we wish to verify whether the twenty-eight item and seven-factor AMS has good reliability and validity, according to SDT assumptions, when adapted to students of these two management areas; we also wish to establish the factorial structure of the AMS that is being adapted and applied to Portuguese Accounting and Marketing undergraduates by building an Accounting and Marketing Academic Motivation Scale (AMAMS) and checking whether it has a satisfactory internal consistency.

\section{Methodology}

The study was conducted in three steps: (1) Translation of AMS English version and its adaptation to AMAMS; (2) Conduction of a pilot survey using modified AMAMS to assess the quality of the items that had been modified (3) Application of AMAMS to Portuguese students of Higher Education Institutions. Details of each step will be presented in the following sections.

\subsection{Adaptation of AMS to AMAMS}

AMAMS was designed to test student motivation among Portuguese college students who attended Accounting and Marketing during the 2017/2018 academic year for the first time. AMS original question "Why do you go to college?" was turned into "Why do you spend time studying Accounting/Marketing? Initially, the original scale was translated from English into Portuguese and back into English again. The reliability and validity of the AMAMS was enabled by a panel of experts on Psychology, Accounting and Marketing, all of them university teachers, who made sure the modified items continued to have the same motivational psychological analysis structure as the AMS and were suitable for Accounting and Marketing students.

All the 28 items of the original AMS suffered minor adjustments and were compared with the new scale so that they could fit the Accounting and Marketing context (see Table 2). In some cases, only "School" was replaced by "Accounting/Marketing"; in other cases, only "Accounting/Marketing" was added; and sometimes changes were more general, regarding the wording of questions to make them suitable for the population under study.

The same scale was used for both CUs because the items that compose it are exactly the same, with the exception of the name of the CUs. Therefore, since the statements were the same for both areas, students could answer the questions about one of the two areas on the same scale. It should be noted that, depending on the area on which data were being gathered, the name of one of the subjects was hidden, to avoid confusing the students. So, whenever data referred to Accounting, Marketing was hidden and vice-versa and the statements remained the same.

The 7-point Likert-type scale of the original AMS, varying between "Does not totally correspond" and "Totally corresponds", was kept and so were all AMOT, EMOT and IMOT variables.

Table 2. Original and modified items of the academic motivation scale

\begin{tabular}{|c|c|c|}
\hline Itens & Original Scale (AMS) & Modified Scale (AMAMS) \\
\hline Question & Why do you go to college? & Why do you spend your time studying Accounting/Marketing \\
\hline AMOT1 & $\begin{array}{l}\text { Honestly, I don't know; I really feel that I am } \\
\text { wasting my time in school. }\end{array}$ & $\begin{array}{l}\text { Honestly, I don't know; I really feel that I am wasting my time } \\
\text { studying Accounting/Marketing. }\end{array}$ \\
\hline AMOT2 & $\begin{array}{l}\text { I can't see why I go to college and frankly, I couldn't } \\
\text { care less. }\end{array}$ & $\begin{array}{l}\text { I can't see why I study Accounting/Marketing and frankly, I couldn't } \\
\text { care less. }\end{array}$ \\
\hline AMOT3 & $\begin{array}{l}\text { I don't know; I can't understand what I am doing in } \\
\text { school. }\end{array}$ & $\begin{array}{l}\text { I don't know; I can't understand what I am doing studying } \\
\text { Accounting/Marketing. }\end{array}$ \\
\hline AMOT4 & $\begin{array}{l}\text { I once had good reasons for going to college; } \\
\text { however, now I wonder whether I should continue. }\end{array}$ & $\begin{array}{l}\text { I'm not sure. I do not see how Accounting/Marketing could be } \\
\text { important to me }\end{array}$ \\
\hline EMER1 & $\begin{array}{l}\text { Because with only a high-school degree I would not } \\
\text { find a high-paying job later on. }\end{array}$ & $\begin{array}{l}\text { Because only with a good grade in Accounting/Marketing, will I find } \\
\text { a high paying job later on. }\end{array}$ \\
\hline EMER2 & In order to obtain a more prestigious job later on. & In order to be able to get a job later on. \\
\hline EMER3 & Because I want to have "the good life" later on. & Because I want to have a good life later on \\
\hline EMER4 & In order to have a better salary later on. & In order to have a better salary later on. \\
\hline EMIN1 & $\begin{array}{l}\text { Because of the fact that when I succeed in college I } \\
\text { feel important. }\end{array}$ & $\begin{array}{l}\text { Because of the fact that when I succeed in everything that is related to } \\
\text { Accounting/Marketing I feel important }\end{array}$ \\
\hline EMIN2 & $\begin{array}{l}\text { To prove to myself that I am capable of completing } \\
\text { my college degree. }\end{array}$ & $\begin{array}{l}\text { To prove the others (teachers, relatives, friends) that I can be good at } \\
\text { Accounting/Marketing. }\end{array}$ \\
\hline EMIN3 & To show myself that I am an intelligent person. & To show myself that I am an intelligent person. \\
\hline EMIN4 & Because I want to show myself that I can succeed in & Because I want to show myself that I can succeed in everything that \\
\hline
\end{tabular}




\begin{tabular}{|c|c|c|}
\hline & my studies. & has to do with Accounting/Marketing. \\
\hline EMID1 & $\begin{array}{l}\text { Because I think that a college education will help me } \\
\text { better prepare for the career I have chosen. }\end{array}$ & $\begin{array}{l}\text { Because I think that Accounting/Marketing will help me better } \\
\text { prepare for the career I have chosen. }\end{array}$ \\
\hline EMID2 & $\begin{array}{l}\text { Because eventually it will enable me to enter the job } \\
\text { market in a field that I like. }\end{array}$ & $\begin{array}{l}\text { Because studying Accounting /Marketing will prove useful for me } \\
\text { later on. }\end{array}$ \\
\hline EMID3 & $\begin{array}{l}\text { Because I believe that a few additional years of } \\
\text { education will improve my competence as a worker. }\end{array}$ & $\begin{array}{l}\text { Because I believe that Accounting/Marketing will improve my } \\
\text { competence as a worker. }\end{array}$ \\
\hline EMID4 & $\begin{array}{l}\text { Because this will help me make a better choice } \\
\text { regarding my career orientation. }\end{array}$ & $\begin{array}{l}\text { Because what I learn in Accounting/Marketing will be very useful } \\
\text { throughout my course. }\end{array}$ \\
\hline IMTA1 & $\begin{array}{l}\text { For the pleasure I experience while surpassing myself } \\
\text { in my studies. }\end{array}$ & $\begin{array}{l}\text { For the pleasure I experience while surpassing myself in } \\
\text { Accounting/Marketing. }\end{array}$ \\
\hline IMTA2 & $\begin{array}{l}\text { For the satisfaction I feel when I am in the process of } \\
\text { accomplishing difficult academic activities. }\end{array}$ & $\begin{array}{l}\text { For the satisfaction I feel when I am in the process of accomplishing } \\
\text { difficult academic activities related to Accounting/Marketing. }\end{array}$ \\
\hline IMTA3 & $\begin{array}{l}\text { For the pleasure that I experience while I am } \\
\text { surpassing myself in one of my personal } \\
\text { accomplishments. }\end{array}$ & Because \\
\hline IMTA4 & $\begin{array}{l}\text { Because college allows me to experience a personal } \\
\text { satisfaction in my quest for excellence in my studies. }\end{array}$ & $\begin{array}{l}\text { Because I experience personal satisfaction if I am knowledgeable } \\
\text { about Accounting/Marketing. }\end{array}$ \\
\hline IMTK1 & $\begin{array}{l}\text { Because I experience pleasure and satisfaction while } \\
\text { learning new things. }\end{array}$ & $\begin{array}{l}\text { Because I experience pleasure and satisfaction while learning new } \\
\text { things about Accounting/Marketing. }\end{array}$ \\
\hline IMTK2 & $\begin{array}{l}\text { For the pleasure I experience when I discover new } \\
\text { things never seen before. }\end{array}$ & $\begin{array}{l}\text { For the pleasure I experience when I discover new things about } \\
\text { Accounting/Marketing that I had never learned before. }\end{array}$ \\
\hline IMTK3 & $\begin{array}{l}\text { For the pleasure that I experience in broadening my } \\
\text { knowledge about subjects which appeal to me. }\end{array}$ & $\begin{array}{l}\text { For the pleasure that I experience in broadening my knowledge about } \\
\text { Accounting/Marketing. }\end{array}$ \\
\hline IMTK4 & $\begin{array}{l}\text { Because my studies allow me to continue to learn } \\
\text { about many things that interest me. }\end{array}$ & $\begin{array}{l}\text { Because studying Accounting/Marketing allows me to learn about } \\
\text { many things in this area. }\end{array}$ \\
\hline IMTS1 & $\begin{array}{l}\text { For the intense feelings I experience when I am } \\
\text { communicating my own ideas to others. }\end{array}$ & $\begin{array}{l}\text { For the intense feelings I experience when I am communicating my } \\
\text { own ideas about Accounting/Marketing to others }\end{array}$ \\
\hline IMTS2 & $\begin{array}{l}\text { For the pleasure that I experience when I read } \\
\text { interesting authors. }\end{array}$ & $\begin{array}{l}\text { For the pleasure that I experience when I learn how things work due } \\
\text { to the agency of Accounting/Marketing. }\end{array}$ \\
\hline IMTS3 & $\begin{array}{l}\text { For the pleasure that I experience when I feel } \\
\text { completely absorbed by what certain authors have } \\
\text { written. }\end{array}$ & $\begin{array}{l}\text { For the pleasure that I experience when I feel completely absorbed by } \\
\text { what the main researchers on Accounting/Marketing have written. }\end{array}$ \\
\hline IMTS4 & $\begin{array}{l}\text { For the "high" feeling that I experience while reading } \\
\text { about various interesting subjects. }\end{array}$ & $\begin{array}{l}\text { For the "high" feeling that I experienced when I read several } \\
\text { interesting studies on Accounting/Marketing. }\end{array}$ \\
\hline
\end{tabular}

\subsection{Pilot Study Using AMAMS}

The AMAMS was used in a series of questionnaires to determine whether the original intention behind AMS items had been maintained and the statements that had been translated were understood by the students. The aim of this pilot study was to make sure the AMAMS did not need any kind of adjustment, improvement or revision to make it more viable. This procedure is very important in assessing the validity of the modified instrument, granting it the required readability and consistency (Barbera \& VandenPlas, 2011).

In the pilot study, AMAMS was applied to 100 Accounting students and 75 Marketing students, thus ensuring that it was valid and reliable. Prior to its application, the questionnaire was read aloud and students were asked to speak out any doubts they might have in both interpreting and rating it according to the Likert scale that was presented to them. Only 4 students showed some doubts regarding the following possible answers: A14 "Because of the fact that when I succeed in everything that is related to Accounting/Marketing I feel important."; A21- "To show myself that I am an intelligent person."; and A25 - "For the "high" feeling that I experienced when I read several interesting studies on Accounting/Marketing".

The statements were explained and doubts clarified and since they only had to do with some linguistic aspects, it was not considered necessary to make any changes. In fact, A14 and A25 did not change much in translation and A21 remained equal to the original scale; therefore, neither the translation nor the context suffered any change. 
Nevertheless, the questionnaire was followed by a brief conversation with the students in order to try and get to the bottom of their doubts. The feedback of that conversation showed that it was all momentary doubts that had been immediately cleared away.

\subsection{Participants}

AMAMS was applied in the form of a paper and online questionnaire to Accounting and Marketing students who attended various Portuguese Higher Education Institutions. The questionnaire was applied during school hours, in coordination with the teachers in charge of the various Higher Education Institutions, in the 1st and 2nd semester of the 2017/2018 school year. Since in some of these Institutions first year students attended Accounting/Marketing only in the 2nd semester, data gathering went on for a whole school year.

The initial questionnaire (M1) was administered between the 2nd and 3rd weeks after classes had begun, and again (M2) in the last week, just before exam season. Students were given thirty minutes to answer the 28 items included in the questionnaire and the sociodemographic data.

Respondents were students aged between 17 and 48 (with an average age of 20.16 years) of which $42 \%$ were male and 58\% are female. There were 1,997 questionnaires gathered from a whole population of 3,083 Accounting students and 484 Marketing students; 74 questionnaires were excluded for not being completely filled in, or for containing more than one answer for one question. 20 out of 24 Higher Education Institutions have participated in the survey, which corresponds to $83.33 \%$ of the public Higher Education Institutions and a total answer rate of 53.91\% (Table 3). Overall, 1,616 valid questionnaires were obtained for Accounting and 307 for Marketing, making a final sample of 1,923 students in a population of 3,567.

Table 3. Sample characterisation

\begin{tabular}{|c|c|c|c|c|c|c|c|c|}
\hline \multirow{2}{*}{ Higher education institutions } & \multirow{2}{*}{ Course } & \multirow{2}{*}{ Population } & \multicolumn{2}{|l|}{$\underline{\text { M1 }}$} & \multicolumn{2}{|l|}{$\underline{\text { M2 }}$} & \multicolumn{2}{|c|}{ Group } \\
\hline & & & $\mathbf{M}$ & $\mathbf{F}$ & $\mathbf{M}$ & $\mathbf{F}$ & GG & GC \\
\hline Polytechnic Institute of Guarda & Management & 40 & 11 & 29 & 11 & 29 & 28 & 12 \\
\hline Polytechnic Institute of Bragança & & 84 & 35 & 40 & 35 & 40 & 48 & 27 \\
\hline Polytechnic Institute of Coimbra & & 20 & -- & -- & -- & -- & -- & -- \\
\hline Polytechnic Institute of Leiria & & 110 & -- & -- & -- & -- & -- & -- \\
\hline Polytechnic Institute of Lisboa & & 195 & 49 & 85 & 49 & 85 & 0 & 134 \\
\hline Polytechnic Institute of Portalegre & & 67 & 9 & 8 & 9 & 8 & 17 & 0 \\
\hline Polytechnic Institute of Viana do Castelo & & 90 & 35 & 23 & 35 & 23 & 38 & 20 \\
\hline ISCTE - University Institute of Lisbon & & 200 & 46 & 32 & 46 & 32 & 54 & 24 \\
\hline University of Beira Interior & & 57 & 30 & 27 & 30 & 27 & 0 & 57 \\
\hline University of Madeira & & 30 & 12 & 18 & 12 & 18 & 20 & 10 \\
\hline University of Aveiro & & 40 & 21 & 10 & 21 & 10 & 31 & 0 \\
\hline Coimbra School of Economics & & 89 & 26 & 23 & 26 & 23 & 0 & 49 \\
\hline University of Évora- School of Social Sciences & & 64 & 22 & 47 & 22 & 47 & 50 & 19 \\
\hline Lisbon School of Economics and Management & & 210 & 30 & 48 & 30 & 48 & 67 & 11 \\
\hline University of Trás-os-Montes e Alto Douro & & 38 & 16 & 22 & 16 & 22 & 24 & 14 \\
\hline University of Algarve & & 140 & 15 & 34 & 15 & 34 & 44 & 5 \\
\hline University of Minho & & 73 & 22 & 35 & 22 & 35 & 35 & 22 \\
\hline Porto School of Economics & & 122 & 45 & 76 & 45 & 76 & 77 & 44 \\
\hline Azores School of Economics and Management & & 27 & 12 & 15 & 12 & 15 & 20 & 7 \\
\hline Lisbon New School of Economics & & 210 & -- & -- & -- & -- & -- & -- \\
\hline ISCTE - University Institute of Lisbon & Economics & 80 & 15 & 20 & 15 & 20 & 0 & 35 \\
\hline University of Beira Interior & & 45 & 15 & 26 & 15 & 26 & 0 & 41 \\
\hline University of Madeira & & 45 & 16 & 24 & 16 & 24 & 30 & 10 \\
\hline University of Aveiro & & 48 & 27 & 21 & 27 & 21 & 0 & 48 \\
\hline Coimbra School of Economics & & 154 & 12 & 20 & 12 & 20 & 0 & 32 \\
\hline University of Évora- School of Social Sciences & & 37 & 10 & 12 & 10 & 12 & 15 & 7 \\
\hline Lisbon School of Economics and Management & & 170 & 65 & 101 & 65 & 101 & 89 & 77 \\
\hline University of Trás-os-Montes e Alto Douro & & 36 & 13 & 23 & 13 & 23 & 36 & 0 \\
\hline University of Algarve & & 25 & 5 & 15 & 5 & 15 & 20 & 0 \\
\hline University of Minho & & 79 & 21 & 56 & 21 & 56 & 45 & 32 \\
\hline
\end{tabular}




\begin{tabular}{|c|c|c|c|c|c|c|c|c|}
\hline Porto School of Economics & & 223 & 26 & 40 & 26 & 40 & 28 & 38 \\
\hline Azores School of Economics and Management & & 25 & 10 & 15 & 10 & 15 & 0 & 25 \\
\hline \multirow[t]{2}{*}{ Lisbon New School of Economics } & & 210 & -- & -- & -- & -- & -- & -- \\
\hline & Total & 3083 & 671 & 945 & 671 & 945 & 816 & 800 \\
\hline Polytechnic Institute of Guarda & Marketing & 26 & 16 & 17 & 16 & 17 & 20 & 13 \\
\hline Polytechnic Institute of Bragança & & 34 & 15 & 12 & 15 & 12 & 18 & 9 \\
\hline Polytechnic Institute of Leiria & & 42 & -- & -- & -- & -- & -- & -- \\
\hline Polytechnic Institute of Setúbal & & 58 & 25 & 33 & 25 & 33 & 40 & 18 \\
\hline Polytechnic Institute of Viseu & & 42 & -- & -- & -- & -- & -- & -- \\
\hline Polytechnic Institute of Porto & & 121 & 20 & 65 & 20 & 65 & 60 & 25 \\
\hline University of Beira Interior & & 33 & 21 & 12 & 21 & 12 & 25 & 8 \\
\hline University of Aveiro & & 50 & -- & -- & -- & -- & -- & -- \\
\hline University of Algarve & & 30 & 14 & 16 & 14 & 16 & 17 & 13 \\
\hline \multirow[t]{2}{*}{ University of Minho } & & 48 & 14 & 27 & 14 & 27 & 15 & 26 \\
\hline & Total & 484 & 125 & 182 & 125 & 182 & 195 & 112 \\
\hline
\end{tabular}

\subsection{Data Analysis}

In order to ascertain the available sample, a descriptive analysis of the data was done, using IBM SPSS 23 software. The internal consistency and reliability of the AMS's items and factors (Pestana \& Gageiro, 2003) adapted for Accounting and Marketing (resulting in the AMAMS) were also checked by means of the Cronbach's Alpha and its respective CFA.

EFA was used to simplify the set of data that were obtained, assessing how much each factor is associated with each variable and examining how all the factors explain the various results obtained in the sample through the sum of the original variables variance (Costello \& Osborne, 2005). After EFA had been done to determine the multifactor nature of the scale, not neglecting how items are spontaneously grouped, the CFA was conducted by means of the Amos 22 software.

The CFA includes a set of techniques that measure the dimensions of a scale (Netemeyer, Bearden, \& Sharma, 2003), and allow one to test hypothesis regarding a number of factors, testing the reliability of the indicators that represent the scale (Raykov \& Marcoulides, 2006). A minimum of five questionnaires per item is often recommended for a factor analysis (Marôco, 2014). Following the CFA, if an item has a high load, it indicates the factor and the item it corresponds to have much in common; loads under 0.32 are considered to be very weak, between 0.32 and 0.45 weak, between 0.45 and 0.63 good and over 0.71 very good (Thompson, 2004).

\section{Results}

\subsection{Confirmatory Factor Analysis}

In Portugal, studies on the AMS structural model are scant; therefore, the original version of the scale, the AMS, was adapted, resulting in the AMAMS, which was applied to both Accounting and Marketing students of Universities and Polytechnic Institutes attending these CUs for the first time. In order to verify whether the factor model of AMAMS was in keeping with the literature, an CFA was then conducted. The choice of the best factor model is essential in CFA, provided factor loads and errors observed statistically validate it and prove its suitability for the study in question (Brown, 2006; Hair, Black, Babin, Anderson, \& Tatham, 2010; Thompson, 2004).

In order to do the CFA, four models were tested - two including the 28 items of the scale and two from which indicators with a factor loading lower than 0.7 were eliminated - with and without variable adjustment, until the one with the statistically most robust results was found. The following models were tested: the original 7 factor model (Mod1); the 5-factor model (Mod2); the 7-factor model with reduction of 4 variables (Mod3); and, finally, the 5-factor model with reduction of 9 variables (Mod4). Table 4 presents the results for the four models that were tested; the original 7 factor model showed a modest adjustment that improved after 4 items were removed. Since previous studies have shown that intrinsic motivation factors can be a single construct (Alivernini \& Lucidi, 2011; Otis et al., 2005), a five factor solution was tested with and without removal of items whose factor loading was lower than 0.7 . Mod2 and Mod4 were then obtained.

As regards the best tested model (Mod4), standardised residual analysis showed that such items as AMOT1, EMER1, EMIN3, IMTA2, IMTA3, IMTA4, IMTK4, IMTS3 and IMTS4 would have to be removed and a model with only 19 items would have to be created instead (Figure 3). The latter, composed by AMOT, EMOT 
(consisting of three factors) and IMOT (grouped in a single factor) revealed a more adequate adjustment, and proved to be the best model of all $(\chi 2=561.215, \mathrm{p}=0.001, \mathrm{df}=128, \chi 2 / \mathrm{df}=4.384$, RMSEA $=0.06, \mathrm{SRMR}$ $=0.0394, \mathrm{NFI}=0.947, \mathrm{GFI}=0.942, \mathrm{AGFI}=0.914$ and $\mathrm{CFI}=0.958)$. Consequently, the 5 -factor structure was better than the original AMS 7 factor model.

Although Mod4 has shown an acceptable adjustment compared to the original model, it should be noted that it was only possible because a number of items were removed so that it could become statistically robust. This led to all items with a factor loading lower than 0.7 (9 out of 28) having been excluded (Hair et al., 2010).

Table 4. Quality index of the adjustments to some of the tested models

\begin{tabular}{|c|c|c|c|c|c|c|}
\hline \multirow[b]{2}{*}{ Adjustment index } & \multicolumn{2}{|l|}{ Mod1 } & \multicolumn{2}{|l|}{$\operatorname{Mod} 2$} & Mod3 & \multirow{2}{*}{$\begin{array}{l}\text { Mod4 } \\
5 \text { Factors - } 19 \text { variables }\end{array}$} \\
\hline & $\begin{array}{l}7 \text { Factors } \\
\text { variables }\end{array}$ & $-\quad 28$ & $\begin{array}{l}5 \text { Factors } \\
\text { variables }\end{array}$ & $-\quad 28$ & $\begin{array}{l}7 \text { Factors }-24 \\
\text { variables }\end{array}$ & \\
\hline$\chi^{2} \quad$ Satorra Bentler & 1747.703 & & 1990.702 & & 1016.996 & 561.215 \\
\hline df & 328 & & 340 & & 226 & 128 \\
\hline p-value & $\mathrm{p}<0.001$ & & $\mathrm{p}<0.001$ & & $\mathrm{p}<0.001$ & $\mathrm{p}<0.001$ \\
\hline$\frac{\chi^{2}}{d f}$ Satorra Bentler & 5.328 & & 5.855 & & 4.500 & 4.384 \\
\hline RMSEA & 0.078 & & 0.082 & & 0.07 & 0.06 \\
\hline SRMR & 0.0625 & & 0.0671 & & 0.0523 & 0.0394 \\
\hline NFI & 0.863 & & 0.846 & & 0.908 & 0.947 \\
\hline GFI & 0.840 & & 0.818 & & 0.891 & 0,942 \\
\hline AGFI & 0.801 & & 0.782 & & 0.856 & 0.914 \\
\hline CFI & 0.887 & & 0.868 & & 0.927 & 0.958 \\
\hline
\end{tabular}

As concerns item and factor reliability, a good total internal consistency was observed $(\alpha=0.93)$ for the sample composed of 1,923 Portuguese students who attended both CUs in the 2017/2018 school year. In view of the 5 -factor structural model that was adopted, the internal consistency of the items was as follows: AMOT $(\alpha=$ $0.83)$; EMOT $(\alpha=0.89)$ and IMOT $(\alpha=0.93)$.

In terms of the final measurement model (Mod 4), Figure 3 presents the standard path coefficients, showing that they were all significant $(\mathrm{p}<0.001)$. AMOT correlates positively with EMIN, but negatively with all of the other factors. The results are concurrent with current literature, according to which AMOT represents the absence of IMOT (Vallerand et al., 1992). EFA and CFA results pointed to a combination of IMOT's three dimensions in the original AMS.

This was not surprising, according to the Self-Determination Theory (Deci \& Ryan, 1985), since the tools AMS uses to measure intrinsic motivation are composed of items that are all very similar and end up being expendable and having to be removed. The 5 factor CFA produced better adjustment indexes than the original 7 factor structure. These results corroborate previous studies (Cokley et al., 2001; Fairchild et al., 2005; Vallerand et al., 1992) that only partially support AMS's seven factor structure. 


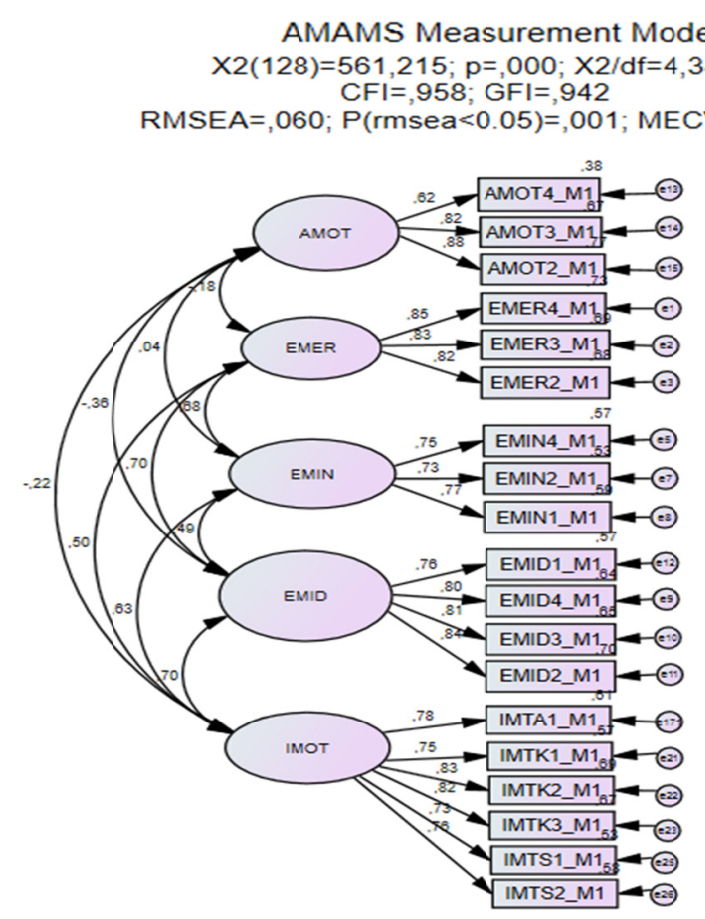

Figure 3. AMAMS's final measurement model

\section{Final Remarks}

In an educational context in general, and, in particular, in the study of Accounting and Marketing, motivation processes are usually explained by means of how much students invest in their learning and the effort and energy they spend on the various activities they are expected to perform. The degree of intrinsic and extrinsic motivation that is directed to learning and to stopping students from dropping out is part of an important motivation process that must be taken into account by pedagogic planning. These processes must be carefully looked into, either within Higher Education Institutions' planning or by the teachers themselves. So, it is vital that policies be designed to successfully reduce the gap between the number of students who enrol in Higher Education and those who actually finish their degree. This is true of Accounting and Marketing, as well as all areas of knowledge and so measures must be taken to ensure more and more promising quantitative and qualitative results.

Using AMS original version, such as was developed by Vallerand et al., (1992), and applying it to different countries and educational contexts is a contribution to advancing scientific knowledge and to the creation of a pattern of empirical knowledge resulting from its application. Additionally, it helps conduct comparative studies involving motivation constructs applied to the teaching/learning process.

Results obtained from a sample of Portuguese students attending Accounting and Marketing for the first time, using a 28 -item scale similar to the original one, allowed us to conclude that, in psychometric terms, this is a statistically reliable measure, which is valid for studying the motivation construct within effective learning in Higher Education.

In that sense, evidence of validity in this study points to the possibility of AMAMS being used to measure student motivation among college students attending Accounting and Marketing. AMAMS's internal structure was tested and assessed in various 5 and 7 factor versions, which sometimes included all the items and sometimes did not, in order to attain the best scale possible that could satisfactorily meet the requirements of statistical viability.

Reliability tests were done which produced high Cronbach's Alpha values in every subscale of AMAMS. Later, a CFA was conducted in order to estimate the best model and results was much similar to those referred to in the literature.

Despite the need for more empirical evidence regarding the suitability of this scale, results obtained from the structural models that were tested allow one to say this is an effective theoretically robust tool to measure 
motivation over the SDT continuum, explaining the various types of motivation and amotivation experienced by students. Both the CFA and the internal consistence provided psychometric evidence that supports the use of a 5 -factor model, in which AMOT and IMOT are incorporated in a single factor and EMOT is subdivided into EMER, EMIN and EMID.

The analyses that were previously done made it possible to change the original AMS scale, adapting it in such a way as to obtain the AMAMS. Validity of AMAMS content was assessed by a panel of experts on Psychology, Accounting and Marketing, who ensured that the changing of items still kept the basic structure of AMS's psychological and motivational analysis and was suitable for students in the field.

A pilot study was also done to assess readability of AMS items after they had been adapted to AMAMS to determine whether students were able to understand the content of each item and their intelligibility.

As regards answers' consistency, it was possible to observe there was consonance with the scale, which meant students understood perfectly what they were being asked. The subscales present in the SDT continuum adapted to Accounting and Marketing provided information regarding students and their attitude to amotivation, intrinsic motivation and extrinsic motivation that can be analysed in a longitudinal study

Thus, motivation is seen as a general multifactor construct, subdivided into intrinsic and extrinsic motivation, which can be affected by amotivation or demotivation, due to the fact that, under certain circumstances, individuals show indifference towards a given reality.

\section{Limitations of the Study and Proposals for Further Research}

The present study obviously has some limitations, starting with the fact that it focused only on students attending Accounting and Marketing in Economics, Management and Marketing courses for the first time. In fact, narrowing the research to these two courses and excluding students from other courses was a limitation that may well become a proposal for further studies. Not to mention the fact that it did not cover all the Higher Education Institutions offering these courses, although its number was significant. Still, it would have been more statistically robust to present results from all institutions. Although the student sample was large, regarding the whole of the population, it did not include all the students; therefore, it was not possible to get the full picture.

We recommend that the measurement tool that has been created and tested be used in other contexts and courses so that AMAMS's psychometric properties can be tested again and results from other sample types can be used to compare different realities.

\section{References}

Alivernini, F., \& Lucidi, F. (2011). Relationship between social context, self-efficacy, motivation, academic achievement, and intention to drop out of high school: A longitudinal study. The Journal of Educational Research, 104(4), 241-252. https://doi.org/10.1080/00220671003728062

Alzhanova-Ericsson, A. T., Bergman, C., \& Dinnétz, P. (2017). Lecture attendance is a pivotal factor for improving prospective teachers' academic performance in Teaching and Learning Mathematics. Journal of Further and Higher Education, 41(1), 1-15. https://doi.org/10.1080/0309877X.2014.1000277

Barbera, J., \& VandenPlas, J. R. (2011). All assessment materials are not created equal: the myths about instrument development, validity, and reliability. In Investigating classroom myths through research on teaching and learning (pp. 177-193). ACS Publications.

Barkoukis, V., Tsorbatzoudis, H., Grouios, G., \& Sideridis, G. (2008). The assessment of intrinsic and extrinsic motivation and amotivation: Validity and reliability of the Greek version of the Academic Motivation Scale. Assessment in Education: Principles, Policy \& Practice, 15(1), 39-55. https://doi.org/10.1080/09695940701876128

Blanchard, S., Vrignaud, P., Lallemand, N., \& Dosnon, O. (1997). Validation de léchelle de motivation en éducation aupres de lycéens francais. Orientation Scolaire et Professionnelle.

Brouse, C. H., Basch, C. E., LeBlanc, M., McKnight, K. R., \& Lei, T. (2010). College Students' Academic Motivation: Differences by Gender, Class, and Source of Payment. College Quarterly, 13(1), 1.

Brown, T. A. (2006). Confirmatory factor analysis for applied research. New York, NY: Guilford.

Browne, M. W., \& Cudeck, R. (1993). Alternative ways of assessing model t. KA Bollen \& JS Long.

Buckley, P., \& Doyle, E. (2016). Gamification and student motivation. Interactive Learning Environments, 24(6), 1162-1175. http://doi.org/10.1080/10494820.2014.964263 
Can, G. (2015). Turkish Version of the Academic Motivation Scale. Psychological Reports, 116(2), 388-408. https://doi.org/10.2466/14.08.PR0.116k24w5

Carbonneau, N., Vallerand, R. J., \& Lafrenière, M. A. K. (2012). Toward a tripartite model of intrinsic motivation. Journal of Personality, 80(5), 1147-1178. https://doi.org/10.1111/j.1467-6494.2011.00757.x

Chiu, M. M., \& Chow, B. W. Y. (2010). Culture, motivation, and reading achievement: High school students in 41 countries. Learning and Individual Differences, 20(6), 579-592. https://doi.org/10.1016/j.lindif.2010.03.007

Cokley, K. O., Bernard, N., Cunningham, D., \& Motoike, J. (2001). A psychometric investigation of the academic motivation scale using a United States sample. Measurement and Evaluation in Counseling and Development, 34(2), 109.

Costello, A. B., \& Osborne, J. W. (2005). Best practices in exploratory factor analysis: Four recommendations for getting the most from your analysis. Practical Assessment, Research \& Evaluation, 10(7), 1-9.

Credé, M., Roch, S. G., \& Kieszczynka, U. M. (2010). Class attendance in college: A meta-analytic review of the relationship of class attendance with grades and student characteristics. Review of Educational Research, 80(2), 272-295. https://doi.org/10.3102/0034654310362998

Deci, E. L., Koestner, R., \& Ryan, R. M. (2001). Extrinsic rewards and intrinsic motivation in education: Reconsidered once again. Review of Educational Research, 71(1), 1-27. https://doi.org/10.3102/00346543071001001

Deci, E. L., \& Ryan, R. M. (1985). The general causality orientations scale: Self-determination in personality. Journal of Research in Personality, 19(2), 109-134. https://doi.org/10.1016/0092-6566(85)90023-6

Deci, E. L., \& Ryan, R. M. (2000). The" what" and" why" of goal pursuits: Human needs and the self-determination of behavior. Psychological Inquiry, 11(4), 227-268. https://doi.org/10.1207/S15327965PLI1104_01

Deci, E. L., \& Ryan, R. M. (2008). Facilitating optimal motivation and psychological well-being across life's $\begin{array}{llll}\text { domains. } & \text { Canadian Psychology/Psychologie } & \text { Canadienne, } & 49(1),\end{array}$ https://doi.org/10.1037/0708-5591.49.1.14

Deci, E. L., \& Ryan, R. M. (2012). Motivation, personality, and development within embedded social contexts: An overview of self-determination theory. The Oxford Handbook of Human Motivation, 85-107.

Eymur, G., \& Geban, Ö. (2011). An investigation of relationship between motivation and academic achievement of pre-service chemistry teachers. Egitim ve Bilim, 36(161), 246.

Fairchild, A. J., Horst, S. J., Finney, S. J., \& Barron, K. E. (2005). Evaluating existing and new validity evidence for the Academic Motivation Scale. Contemporary Educational Psychology, 30(3), 331-358. https://doi.org/10.1016/j.cedpsych.2004.11.001

Glynn, S. M. (2007). in Science Learning. Handbook of Research on Science Education, 1, 75.

Goldschmidt, M., \& Bogner, F. X. (2016). Learning about genetic engineering in an outreach laboratory: Influence of motivation and gender on students' cognitive achievement. International Journal of Science Education, Part B, 6(2), 166-187. https://doi.org/10.1080/21548455.2015.1031293

González, A., \& Paoloni, P. V. (2015). Perceived autonomy-support, expectancy, value, metacognitive strategies and performance in chemistry: a structural equation model in undergraduates. Chemistry Education Research and Practice, 16(3), 640-653. https://doi.org/10.1039/C5RP00058K

Gottfried, A. E., Marcoulides, G. A., Gottfried, A. W., Oliver, P. H., \& Guerin, D. W. (2007). Multivariate latent change modeling of developmental decline in academic intrinsic math motivation and achievement: Childhood through adolescence. International Journal of Behavioral Development, 31(4), 317-327. https://doi.org/10.1177/0165025407077752

Guay, F., Morin, A. J. S., Litalien, D., Valois, P., \& Vallerand, R. J. (2015). Application of exploratory structural equation modeling to evaluate the academic motivation scale. The Journal of Experimental Education, 83(1), 51-82. https://doi.org/10.1080/00220973.2013.876231

Hair, J. F., Black, W. C., Babin, B. J., Anderson, R. E., \& Tatham, R. (2010). L.(2010). Multivariate data analysis. Pearson.

Hardre, P. L., \& Reeve, J. (2003). A motivational model of rural students' intentions to persist in, versus drop out 
of, high school. Journal of Educational Psychology, 95(2), 347. https://doi.org/10.1037/0022-0663.95.2.347

He, W., Gajski, D., Farkas, G., \& Warschauer, M. (2015). Implementing flexible hybrid instruction in an electrical engineering course: The best of three worlds? Computers \& Education, 81, 59-68. https://doi.org/10.1016/j.compedu.2014.09.005

Huett, J. B., Kalinowski, K. E., Moller, L., \& Huett, K. C. (2008). Improving the motivation and retention of online students through the use of ARCS-based e-mails. The Amer. Jrnl. of Distance Education, 22(3), 159-176. https://doi.org/10.1080/08923640802224451

Jang, H. (2008). Supporting students' motivation, engagement, and learning during an uninteresting activity. Journal of Educational Psychology, 100(4), 798. https://doi.org/10.1037/a0012841

Joly, M. C. R. A., \& Prates, E. A. R. (2011). Avaliação da escala de motivação acadêmica em estudantes paulistas: $\begin{array}{lllll}\text { propriedades } & \text { psicométricas. } & \text { Psico-USF, } & 16(2), & 175-184 .\end{array}$ https://doi.org/10.1590/S1413-82712011000200006

Lim, S. Y., \& Chapman, E. (2015). Adapting the academic motivation scale for use in pre-tertiary mathematics classrooms. Mathematics Education Research Journal, 27(3), 331-357. https://doi.org/10.1007/s13394-014-0140-9

Marôco, J. (2014). Análise estatística com o SPSS Statistics.

Maurer, T., Allen, D., Gatch, D. B., Shankar, P., \& Sturges, D. (2012). Students' academic motivations in allied health classes. Internet Journal of Allied Health Sciences and Practice, 10(1), 6.

Morrissey, T. W., Hutchison, L., \& Winsler, A. (2014). Family income, school attendance, and academic achievement in elementary school. Developmental Psychology, 50(3), 741. https://doi.org/10.1037/a0033848

Netemeyer, R. G., Bearden, W. O., \& Sharma, S. (2003). Scaling procedures: Issues and applications. Sage Publications. https://doi.org/10.4135/9781412985772

Nilsson, K. E. L., \& Stomberg, M. I. W. (2008). Nursing students motivation toward their studies--a survey study. BMC Nursing, 7(1), 6. https://doi.org/10.1186/1472-6955-7-6

Ntoumanis, N. (2002). Motivational clusters in a sample of British physical education classes. Psychology of Sport and Exercise, 3(3), 177-194. https://doi.org/10.1016/S1469-0292(01)00020-6

Núñez Alonso, J. L., Mart'in-Albo Lucas, J., \& Navarro Izquierdo, J. G. (2005). Validación de la versión española de la Échelle de Motivation en Éducation. Psicothema, 17(2).

Orsini, C., Evans, P., Binnie, V., Ledezma, P., \& Fuentes, F. (2016). Encouraging intrinsic motivation in the clinical setting: teachers' perspectives from the self-determination theory. European Journal of Dental Education, 20(2), 102-111. https://doi.org/10.1111/eje.12147

Otis, N., Grouzet, F. M. E., \& Pelletier, L. G. (2005). Latent Motivational Change in an Academic Setting: A 3-Year Longitudinal Study. Journal of Educational Psychology, 97(2), 170. https://doi.org/10.1037/0022-0663.97.2.170

Palacios, A., Arias, V., \& Arias, B. (2014). Attitudes towards mathematics: Construction and validation of a measurement instrument. Revista de Psicodidáctica, $19(1), \quad 67-91$. https://doi.org/10.1387/RevPsicodidact.8961

Pestana, M. H., \& Gageiro, J. N. (2003). Análise de dados para ciências sociais: a complementaridade do SPSS.

Pintrich, P. R. (2003). A motivational science perspective on the role of student motivation in learning and teaching contexts. Journal of Educational Psychology, 95(4), 667. https://doi.org/10.1037/0022-0663.95.4.667

Pintrich, P. R., Smith, D. A. F., Garcia, T., \& McKeachie, W. J. (1993). Reliability and predictive validity of the Motivated Strategies for Learning Questionnaire (MSLQ). Educational and Psychological Measurement, 53(3), 801-813. https://doi.org/10.1177/0013164493053003024

Ramos, S. I. (2013). Motivação académica dos alunos do ensino superior. Psicologia. Pt.

Ratelle, C. F., Guay, F., Larose, S., \& Senécal, C. (2004). Family Correlates of Trajectories of Academic Motivation During a School Transition: A Semiparametric Group-Based Approach. Journal of Educational Psychology, 96(4), 743. https://doi.org/10.1037/0022-0663.96.4.743 
Ratelle, C. F., Guay, F., Vallerand, R. J., Larose, S., \& Senécal, C. (2007). Autonomous, controlled, and amotivated types of academic motivation: A person-oriented analysis. Journal of Educational Psychology, 99(4), 734. https://doi.org/10.1037/0022-0663.99.4.734

Raykov, T., \& Marcoulides, G. A. (2006). Estimation of generalizability coefficients via a structural equation modeling approach to scale reliability evaluation. International Journal of Testing, 6(1), 81-95. https://doi.org/10.1207/s15327574ijt0601_5

Ryan, R. M., \& Deci, E. L. (2000a). Intrinsic and Extrinsic Motivations : Classic Definitions and New Directions, 67, 54-67. http://doi.org/10.1006/ceps.1999.1020

Ryan, R. M., \& Deci, E. L. (2000b). Intrinsic and extrinsic motivations: Classic definitions and new directions. Contemporary Educational Psychology, 25(1), 54-67. https://doi.org/10.1006/ceps.1999.1020

Ryan, R. M., \& Deci, E. L. (2000c). Self-determination theory and the facilitation of intrinsic motivation, social development, and well-being. American Psychologist, 55(1), 68. https://doi.org/10.1037/0003-066X.55.1.68

Smith, K. J., Davy, J. A., \& Rosenberg, D. L. (2010). An examination of the validity of the Academic Motivation Scale with a United States business student sample. Psychological Reports, 106(2), 323-341. https://doi.org/10.2466/pr0.106.2.323-341

Sobral, D. T. (2003). Motivação do aprendiz de medicina: uso da escala de motivação acadêmica. Psicologia: Teoria e Pesquisa, 19(1), 25-31. https://doi.org/10.1590/S0102-37722003000100005

Spittle, M., Jackson, K., \& Casey, M. (2009). Applying self-determination theory to understand the motivation for becoming a physical education teacher. Teaching and Teacher Education, 25(1), 190-197. https://doi.org/10.1016/j.tate.2008.07.005

Stover, J. B., de la Iglesia, G., Boubeta, A. R., \& Liporace, M. F. (2012). Academic Motivation Scale: adaptation and psychometric analyses for high school and college students. Psychology Research and Behavior Management, 5, 71. https://doi.org/10.2147/PRBM.S33188

Sturges, D., Maurer, T. W., Allen, D., Gatch, D. B., \& Shankar, P. (2016). Academic performance in human anatomy and physiology classes: a 2-yr study of academic motivation and grade expectation. Advances in Physiology Education, 40(1), 26-31. https://doi.org/10.1152/advan.00091.2015

Taylor, G., Jungert, T., Mageau, G. A., Schattke, K., Dedic, H., Rosenfield, S., \& Koestner, R. (2014). A self-determination theory approach to predicting school achievement over time: The unique role of intrinsic motivation. Contemporary Educational Psychology, 342-358. https://doi.org/10.1016/j.cedpsych.2014.08.002

Thompson, B. (2004). Exploratory and confirmatory factor analysis: Understanding concepts and applications. American Psychological Association. https://doi.org/10.1037/10694-000

Tinto, V. (2006). Research and practice of student retention: What next? Journal of College Student Retention: Research, Theory \& Practice, 8(1), 1-19. https://doi.org/10.2190/4YNU-4TMB-22DJ-AN4W

Tóth-Király, I., Orosz, G., Dombi, E., Jagodics, B., Farkas, D., \& Amoura, C. (2017). Cross-cultural comparative examination of the Academic Motivation Scale using exploratory structural equation modeling. Personality and Individual Differences, 106, 130-135. https://doi.org/10.1016/j.paid.2016.10.048

Tseng, S. C., \& Tsai, C. C. (2010). Taiwan college students' self-efficacy and motivation of learning in online peer assessment environments. The Internet and Higher Education, 13(3), 164-169. https://doi.org/10.1016/j.iheduc.2010.01.001

Utvær, K. S. B. (2014). Explaining health and social care students' experiences of meaningfulness in vocational education: The importance of life goals, learning support, perceived competence, and autonomous motivation. Scandinavian Journal of Educational Research, 58(6), 639-658. https://doi.org/10.1080/00313831.2013.821086

Vallerand, R. J. (1997). Toward a hierarchical model of intrinsic and extrinsic motivation. Advances in Experimental Social Psychology, 29, 271-360. https://doi.org/10.1016/S0065-2601(08)60019-2

Vallerand, R. J., Blais, M. R., Brière, N. M., \& Pelletier, L. G. (1989). Construction et validation de l'échelle de motivation en éducation (EME). Canadian Journal of Behavioural Science/Revue Canadienne Des Sciences Du Comportement, 21(3), 323. https://doi.org/10.1037/h0079855

Vallerand, R. J., \& Blssonnette, R. (1992). Intrinsic, extrinsic, and amotivational styles as predictors of behavior: 
A prospective study. Journal of $\quad$ Personality, $\quad 60(3), \quad$ 599-620. https://doi.org/10.1111/j.1467-6494.1992.tb00922.x

Vallerand, R. J., Pelletier, L. G., Blais, M. R., Briere, N. M., Senecal, C., \& Vallieres, E. F. (1992). The Academic Motivation Scale: A measure of intrinsic, extrinsic, and amotivation in education. Educational and Psychological Measurement, 52(4), 1003-1017. https://doi.org/10.1177/0013164492052004025

Vallerand, R. J., Pelletier, L. G., Blais, M. R., Brière, N. M., Senecal, C., \& Vallieres, E. F. (1993). On the assessment of intrinsic, extrinsic, and amotivation in education: Evidence on the concurrent and construct validity of the Academic Motivation Scale. Educational and Psychological Measurement, 53(1), 159-172. https://doi.org/10.1177/0013164493053001018

Vansteenkiste, M., Lens, W., \& Deci, E. L. (2006). Intrinsic versus extrinsic goal contents in self-determination theory: Another look at the quality of academic motivation. Educational Psychologist, 41(1), 19-31. https://doi.org/10.1207/s15326985ep4101_4

Vecchione, M., Alessandri, G., \& Marsicano, G. (2014). Academic motivation predicts educational attainment: Does gender make a difference? Learning and Individual Differences, 32, 124-131. https://doi.org/10.1016/j.lindif.2014.01.003

Wang, J. C. K., Hagger, M., \& Liu, W. C. (2009). A cross-cultural validation of perceived locus of causality scale in physical education context. Research Quarterly for Exercise and Sport, 80(2), 313-325. https://doi.org/10.1080/02701367.2009.10599566

Wigfield, A. (1994). Expectancy-value theory of achievement motivation: A developmental perspective. Educational Psychology Review, 6(1), 49-78. https://doi.org/10.1007/BF02209024

Yen, H. C., Tuan, H. L., \& Liao, C. H. (2011). Investigating the influence of motivation on students' conceptual learning outcomes in web-based vs. classroom-based science teaching contexts. Research in Science Education, 41(2), 211-224. https://doi.org/10.1007/s11165-009-9161-X

\section{Copyrights}

Copyright for this article is retained by the author(s), with first publication rights granted to the journal.

This is an open-access article distributed under the terms and conditions of the Creative Commons Attribution license (http://creativecommons.org/licenses/by/4.0/). 